\title{
Survey of Overwintering Trait In Chinese Rice Cultivars (Oryza Sativa L)
}

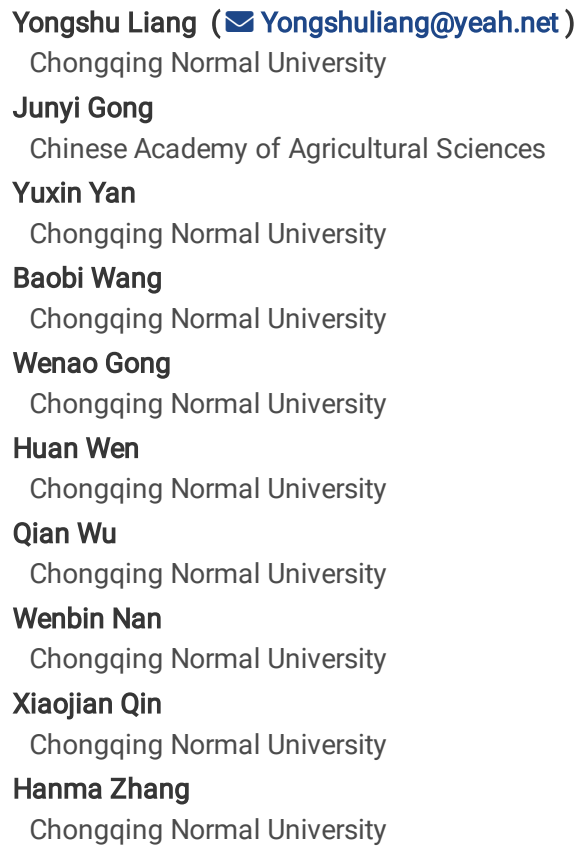




\section{Abstract}

Overwintering $(\mathrm{OW})$ rice can survive through the natural cold-winter field environment, exhibit a strong root system activity, sprout from rice tillering node in the following spring, and apparently reveal the cold resistance of rice during the whole growth stage. The successful utilization of cold-resistant rice is the most economical strategy for the cold-resistant rice cultivar breeding. This work aims to identify the OW rice for the future development of cold-resistant cultivars. Altogether 1034 Chinese rice cultivars were evaluated for their responses to low temperatures under the natural field cold-winter environment. The heading date $(\mathrm{HD}, \mathrm{d})$ and plant height $(\mathrm{PH}, \mathrm{cm})$ of 1034 rice cultivars ranged from 65 to $140 \mathrm{~d}$ in 2019, 65 to $150 \mathrm{~d}$ in 2020, ranged from 60 to $140 \mathrm{~cm}$ in 2019,60 to $150 \mathrm{~cm}$ in 2020, and displayed slight difference between 2019 and 2020. Among them, altogether 262 (25.34\%) Japonica rice cultivars could withstand cold to $4^{\circ} \mathrm{C}$ in December 2019 and distributed in 13 provinces of China, survive through the natural cold-winter field environment, and sprout from rice tillering node in March 2020. Only 24 (2.32\%) japonica rice cultivars with resistance to $0^{\circ} \mathrm{C}$ in January 2021 distributed in seven provinces of China could also sprout from rice tillering node in March 2021. The present cold-resistant rice cultivars will provide beneficial breeding germplasm for future cold-resistant rice breeding and new strategies in elucidating the molecular mechanism of the cold resistance of rice.

\section{Introduction}

Rice (Oryza sativa L.) is one of the most important crops in China and provides stable food for approximately half of the global population (Fairhurst and Dobermann, 2002). The global rice production is 759.6 million tons, where China ranks first in terms of the area and total production (Cheng, 2010). For a long time, the innovative utilization of rice germplasm has promoted the development of rice genetics and breeding project (Yuan, 1966; Cheng, 2010). The successful breeding of each new rice variety with good quality and high yield and the publication of each world-class paper of rice are indispensable to the innovative utilization of excellent rice germplasm (Zeng et al., 2000; Qin et al., 2021). In addition, rice germplasm plays an important role in the rice genetic and breeding project for ever, laying a good material foundation on the study of basic theory and application of rice.

Compared with wheat (Triticum aestivum L.) and bamboo (Phyllostachys) of Poaceae, rice is more sensitive to low temperature and can easily be damaged from cold throughout the world (Zhang et al., 2017). Particularly in China, the low-temperature disaster leads to the loss of 300-500 million tons of grain per year (Zhu et al., 2015; Zhang et al., 2017). Breeding a cold-resistant rice variety is the best economic strategy involved in reducing the loss of grain cold damage. In rice production, cold damage usually occurs at several different stages of germination, seedling, booting, and mature growth of rice (Dai et al., 2004; Oliver et al., 2005; Kuroki et al., 2007; Zhou et al., 2010; Shinada et al., 2013; Zhao et al., 2015; Pan et al., 2015; Wang et al., 2016; Shakiba et al., 2017). Consequently, rice geneticists and breeders paid additional attention to the physiological and biochemical indexes and the genetic mechanism of cold resistance in rice at several different stages of germination, seedling, booting, and reproductive growth. Presently, the variation of physiological and biochemical indexes of cold resistance in rice has been reported. Examples include proline (Zhang et al., 2014), chlorophyll content (Paknejad et al., 2007), electrolyte leakages (Los and Murata, 2004), reactive oxygen species (Mittal et al., 2012), malondialdehyde (Pamplona, 2011), soluble sugar (Ma et al., 2009), abscisic acid (Mittler and Blumwald, 2015), and gibberellin (Sakata et al., 2014). From another perspective, the cold resistance in rice is a typical quantitative inheritance trait, controlled by multiple quantitative trait loci (QTLs) (Zhang et al., 2014). A series of excellent cold-resistant rice germplasms including Silewah, Koshihikari, M202, Norin-PL8, Dongxiangwildrice, Kunmingxiaobaigu, and Lijiangxintuanhei were selected as the donor parent for the identification of QTL underlying cold resistance. Currently, more than 250 QTLs controlling cold resistance have been roughly located on 12 chromosomes of rice using phenotypic data on cold resistance at several different stages of germination, seedling, booting, and mature growth of rice (Andaya and Mackill 2003; Liu et al., 2003; Xu et al., 2008; Kuroki et al., 2009; Mori et al., 2011; Shirasawa et al., 2014; Biswas et al., 2017). Among them, five QTLs (qLTB3, qCTB7, qCTB8, qCT-3-2, and qCTB10-2) underlying cold resistance at the booting stage of rice have been finely mapped (Endo et al., 2016; Zhou et al., 2010; Kuroki et al., 2007; Zhu et al., 2015; Li et al., 2018). Other five QTLs (qCTS4, qCtss11, qSCT1, qSCT11, qLOP2, and qPSR2-1) have been finely mapped at the seedling stage (Andaya and Tai, 2007; Koseki et al., 2010; Kim et al., 2014; Xiao et al., 2015). QRC10-2 and qLTG-9 underlying the cold-resistant trait have been finely mapped at the seedling, mature, germinating stages of rice. In particular, seven QTLs (qLTG3-1, COLD1, qCTS-9, GSTZ2, LTG1, Ctb1, and CTB4a) have been cloned and functionally identified for the cold resistance of rice at some stage of germination or seedling or booting or vegetative growth of rice (Fujino et al., 2008; Saito et al., 2010; Jiang et al., 2010; Kim et al., 2011; Lu et al., 2014; Ma et al., 2015; Zhao et al., 2017). The present study has promoted the development of stress biology in rice. However, the cold resistance of rice cultivars during the whole growth stage will not be given more emphasis even if China exhibited abundant cold-tolerant rice germplasm resources.

Currently, knowledge about the cold resistance during the whole growth stage in Chinese rice cultivars is still limited. The overwintering (OW) rice germplasm is an extreme case of cold resistance of rice, which can survive through the cold winter season and sprout from rice tillering node in the following spring even if the rice stubble is exposed to the natural cold-winter field environment. The field overwintering phenomenon of OW rice will be regarded as the highest state of cold resistance throughout the whole growth stage and can well reveal the cold resistance of rice cultivars during the whole growth stage. However, the widely planted ratooning rice is a type of special Indica variety, which can be planted once a year but harvested twice in rice production within single year, which sprouted from the rice pile axillary after being harvested before the winter coming (Chauhan 1985, Xu et al., 2015). However in this study, the OW rice germplasm exhibited significant different from the widely planted ratooning rice cultivars that couldn't survive through the cold winter season after being exposed to the natural cold-winter field environmental and couldn't sprout from rice tillering node in the following spring even if about 0.4 million $\mathrm{hm}^{2}$ ratooning rice with 4.5 t.hm ${ }^{-2}$ have been widely planted in South China (Xu et al., 2002, 2015). Recently, the genetic of OW (perennial) trait in Chinese perennial Dongxiang wild rice and OW rice cultivars has been preliminary reported (Liang et al., 2018). The perennial rice variety has been successfully developed by selecting Oryza longistaminate as gene donors and commercially released to farmers (Hu et al., 2003; Zhang et al., 2014; Huang et al., 2018). However, the OW trait of Chinese rice cultivars is still unknown and has not been given more attention although approximately 2124 rice cultivars have been successfully developed and commercially released to farmers (www.rice data.com). Currently, there a little about the OW characteristic of Chinese rice cultivars has been publicly reported (Liang et al., 2021). However, the OW characteristics of Chinese rice cultivars and their backbone parent including maintainer lines, restorer lines, and Indica/ Japonica conventional rice cultivars is still unknown. Therefore, it is necessary for the study on OW characteristics of Chinese rice cultivars 
even though the OW rice is a type of novel genetic and breeding germplasm. This study aims to evaluate the OW trait of Chinese rice cultivars for future coldresistant rice breeding or even understanding the genetic mechanism of OW characteristics of rice.

\section{Materials And Methods}

\section{Rice cultivars}

The 1034 Chinese rice cultivars in this study were obtained from the National Center for Rice Improvement, China National Rice Research Institute (CNRRI), Zhejiang Province, China, and are widely planted or applied in the hybrid rice breeding project. The 735 (71.08\%) rice cultivars are conventional Japonica rice cultivars and the remaining 299 (28.92\%) Indica rice cultivars were widely used in rice hybrid breeding, including 32 (3.09\%) maintainer lines, 242 (23.40\%) restorer lines, and $25(2.42 \%)$ conventional indica rice cultivars. Most of the rice seeds were provided by Professor Gong (CNRRI).

\section{Description of field screening experiments}

Rice field experiments between March 2019 and March 2021 were conducted at the Rice Biotechnology Testing Station of Chongqing Normal University (CQNU), Shapingba district, Chongqing (29³2'N, 106³2'E), P. R. China. In March 2019, the seeds of all 1034 rice cultivars were sown on 13 March 2019 . The 40-day-old seedlings of all tested rice were transplanted into a single row with five plants, having a 20-cm gap between plants within each row and a 25 -cm gap between rows (Figure 4.a). Similarly, a parallel test was performed repeatedly in March 2020, and the seeds of 1034 rice cultivars were also sown. The 40day-old seedlings of 1034 rice cultivars were also transplanted into a single row with five plants, having a 20-cm gap between plants within each row and a 25cm gap between rows (Figure 6.a). The rice stubble of 1034 rice cultivars was retained in crop field after being harvested in August 2019 and 2020 and exposed to the natural field cold-winter environment for OW rice germplasm evaluated (Figure 4.b; Figure 6.b).

A rice compound fertilizer ( $375 \mathrm{~kg} \mathrm{ha}^{-1}$ ) occupied more than $40 \%$ of the total nutrients, was made up of $18 \% \mathrm{~N}, 8 \% \mathrm{P}_{2} \mathrm{O}_{5}$, and $14 \% \mathrm{~K}_{2} \mathrm{O}$, and was used as base fertilizer for rice. Nitrogen fertilizer $\left(60 \mathrm{~kg} \mathrm{ha}{ }^{-1}, 46 \% \mathrm{~N}\right)$ and seedling herbicide were applied 2 weeks after transplanting. The water management strategy was adapted to shallow water at the transplanting stage and flooding mid-season with drainage-reflooding-moist intermittent irrigation. Disease, pest, and weed management were carried out at different growth stages.

\section{Climatic condition for OW rice cultivars evaluated}

Winter in Chongqing including November, December, January, and February exhibited the lowest daily minimum (Min $\mathrm{T}$, $\left.{ }^{\circ} \mathrm{C}\right)$ temperature throughout the whole year. For a long time, the daily minimum (Min $\mathrm{T},{ }^{\circ} \mathrm{C}$ ) temperature of the rice experimental field at the Rice Biotechnology Testing Station of CQNU usually occurs in December and January per year in Chongqing. Consequently, the daily minimum (Min T, ${ }^{\circ} \mathrm{C}$ ) temperatures in both December 2019 and January 2021 were applied to the referable index on field experiment climatic conditions for OW rice germplasm evaluated. At the present field experiment, meteorological data on the daily minimum (Min T, ${ }^{\circ} \mathrm{C}$ ) and maximum (Max T, ${ }^{\circ} \mathrm{C}$ ) temperatures from November 2019 and 2020 to February 2020 and 2021 for 0 W rice cultivar evaluated were collected from the Shapingba district weather station nearby the Rice Biotechnology Testing Station of CQNU, Chongqing. The mean daily temperature and its standard derivation (SD) were calculated with the statistical software GraphPadPrism5.0, respectively. The broken line chart was drawn using Microsoft Excel 2010.

\section{Evaluation of OW rice cultivars through the natural cold-winter environment}

The rice stubbles of 1034 Chinese rice cultivars were retained in crop field after being harvested in August 2019 and 2020 . And then, all tested rice stubble would be exposed to the natural cold-winter field environment from November 2019 and 2020 to March 2020 and 2021. The winter in Chongqing turns to spring in mid-February, the daily minimum (Min T, ${ }^{\circ} \mathrm{C}$ ) temperature of Chongqing began to rise in mid-to-late February 2020 and 2021 (Table 1 ). The rice cultivars could survive through the natural cold-winter field environment, display withering stems and leaves but a strong root activity, and sprout from rice tillering node in March and April 2021, and finally was designed as OW rice germplasm (Figure 6.c-e). Although, the widely planted ratooning rice can be planted once a year but harvested twice in rice production within single year, sprouts from the rice pile axillary after the rice being harvested in crop field (Chauhan 1985, Xu et al., 2015). In particularly, the ratooning rice displays withering roots, stems and leaves before the winter coming and cannot survive through the natural cold-winter field environment. In summary, two criteria were employed to distinguish OW rice from rationing rice in crop field. One is that OW rice can survive through the natural cold-winter field environment, exhibit withering stems and leaves but strong root system activity, and sprout from rice tillering node in the following spring (Figure 6.c-e); Another is that the ratooning rice will be withered and exhibit withering root system, stems and leaves before the Winter coming and sprout from the rice pile axillary after being harvested in the fall of that year.

\section{Evaluation of heading date and plant height of 1034 rice cultivars}

The 1034 Chinese rice cultivars were planted into a single row with five plants in crop field. Three plants in the middle of single row were selected to investigate both heading date (HD, d) and plant height $(\mathrm{PH}, \mathrm{cm})$ of each rice cultivar in both 2019 and 2020. At heading stage, HD was recorded as days from the time of sowing to that of the first panicle flowering of three plants in the middle of single row of each rice cultivar. At mature stage, $\mathrm{PH}$ (in $\mathrm{cm}$ ) was measured from the soil surface to the tip of the tallest panicle of three plants in the middle of single row of each rice cultivar. The average values of three plants of $\mathrm{HD}$ and $\mathrm{PH}$ trait within single row of each rice cultivar were arranged for the statistical analysis.

\section{Results}

\section{Climatic condition}


Meteorological data on daily minimum (Min T, ${ }^{\circ} \mathrm{C}$ ) and maximum (Max T, ${ }^{\circ} \mathrm{C}$ ) temperatures from November 2019 and 2020 to February 2020 and 2021 were collected from the Shapingba district weather station nearby the Rice Biotechnology Testing Station of CQNU (Table 1). Winter in Chongqing including November, December, January and February displayed the lowest daily minimum temperature throughout the whole year. Winter in Chongqing turns to spring in mid-February, and then, the daily minimum temperature of Chongqing began to rise in mid-to-late February 2020 and 2021 . From November 2019 and 2020 to February 2020 and 2021 , the lowest average daily minimum temperatures were $6.61^{\circ} \mathrm{C}$ (December 2019) and $3.87^{\circ} \mathrm{C}($ January 2021$)$, respectively.

A significant difference exists on average the lowest daily minimum temperatures between December 2019 and January 2021 (Table 1). The lowest average daily minimum temperature exhibited the lowest temperature of $6.61{ }^{\circ} \mathrm{C}$ in December 2019 . The lowest daily minimum temperature with $4^{\circ} \mathrm{C}$ occurred on December 6 and 28,2019 and exhibited a shallow range from $4^{\circ} \mathrm{C}$ on December 6 and 28 to $10^{\circ} \mathrm{C}$ on December 14 and 15 . Particularly in December 2019 , the daily minimum temperature of $0^{\circ} \mathrm{C}$ did not occur. However, the lowest average daily minimum temperature was $3.87^{\circ} \mathrm{C}$ in January 2021 . Particularly in January 2021 , the lowest daily minimum temperature at $0{ }^{\circ} \mathrm{C}$ for three days occurred on January 11,12 , and 17 and exhibited a wide range of temperature from $0{ }^{\circ} \mathrm{C}$ on January 11,12 and 17 to $7{ }^{\circ} \mathrm{C}$ on January 28-31. The daily minimum temperature of $1^{\circ} \mathrm{C}$ within three days occurred on January 14,17 , and 18 , and the daily minimum temperature of $2^{\circ} \mathrm{C}$ within seven days occurred on January $1,7,8,10,13,15$, and 16 . The daily minimum temperature in January 2021 exhibited the biggest coefficient variation (CV) value of $63.80 \%$. Screening pressure on the daily minimum temperature in January 2021 is significant stronger than that of December 2019. Consequently, the low-temperature climate in January 2021 evaluated the OW rice germplasm more precisely than that of December 2019.

\section{Evaluation of heading date of 1034 rice cultivars}

Altogether 1034 Chinese rice cultivars were planted into a single row with five plants in crop field (Figure 4.a, Figure 6.a). Three plants in the middle of single row were selected to investigate heading date (HD, d) of each rice cultivar in both 2019 and 2020 (data not shown). The average HD of 1034 rice cultivars in both 2019 and 2020 were 103.38(d) and 101.59(d), displayed slight difference between 2019 and 2020 due to the different external climatic environment. The number of rice cultivars at HD displayed normal distribution in both 2019 and 2020 (Figure 2). The HD of 1034 rice cultivars ranged from 65 to 140 d in 2019 , ranged from $65 \mathrm{~d}$ to $150 \mathrm{~d}$ in 2020. The maximum number of 166 (2019) and 167 (2020) rice cultivars displayed 95-day HD. There 809 (2019) and 806 (2020) rice cultivars densely distributed during the heading period of 85-day to 120-days, the number of rice cultivars displayed slight difference on frequency distribution of HD between 2019 and 2020 due to the different external climatic environment.

\section{Evaluation of plant height of 1034 rice cultivars}

The 1034 rice cultivars were planted into a single row with five plants in crop field (Figure 4.a, Figure 6.a). Three plants in the middle of single row were selected to investigate plant height $(\mathrm{PH}, \mathrm{cm})$ of each rice cultivar in both 2019 and 2020 (data not shown). The average $\mathrm{PH}$ (cm) of 1034 rice cultivars was $96.82 \mathrm{~cm}$ in 2019 and $99.17 \mathrm{~cm}$ in 2020, displayed slight difference between 2019 and 2020, and slightly affected by external climatic environment. The number of rice cultivars at PH displayed normal distribution in both 2019 and 2020 (Figure 3). The PH of 1034 rice cultivars ranged from 60 to $140 \mathrm{~cm}$ in 2019,60 to $150 \mathrm{~cm}$ in 2020. The maximum number of 147 (2019) and 117 (2020) rice cultivars densely displayed 95-cm PH. There 851 (2019) and 817 (2020) rice cultivars densely displayed the plant height of between $80 \mathrm{~cm}$ to $120 \mathrm{~cm}$, the number of rice cultivars displayed slight difference on frequency distribution of $\mathrm{PH}$ between 2019 and 2020 due to the different external environment.

\section{Evaluation of OW rice cultivar with resistance to $4^{\circ} \mathrm{C}$}

The 1034 rice cultivars have been exposed to the natural field cold-winter environment after being harvested from November 2019 to February 2020 (Figure 4.b). Among them, 262 (25.34\%) Japonica rice cultivars could withstand cold damage of $4{ }^{\circ} \mathrm{C}$ on December 6 and 28,2019 (Table $2,3,4$ ), which could survive through the natural cold-winter field environment, stay strong activity of stems and leaves, and sprout from rice tillering node in March 2020 (Figure 4 . b-d, Table 2-4). The remaining 772 rice cultivars with the withered root system could not sprout from rice tillering node in March 2020 and might not carry the gene or QTLs controlling the OW trait. No Indica rice cultivars were found to withstand resistance to $4{ }^{\circ} \mathrm{C}$.

A total of 262 OW rice cultivars are distributed in 13 different provinces or cities of China and range from 2 (0.76\%) in Heilongjiang province to 65 (24.81\%) in Liaoning province (Figure 5, Table 2-4). Of these, the cultivated rice from Liaoning had $65(24.81 \%)$ rice cultivars and exhibited the first highest percentage of OW rice cultivars with resistance to $4^{\circ} \mathrm{C}$. Rice cultivars in provinces of Jiangsu, Jilin, Tianjin, and Yunnan exhibiting 41 (15.65\%), 29 (11.07\%), 28 (10.68\%), and $24(9.16 \%)$, respectively, provide a relative higher percentage of OW rice cultivars with resistance to $4{ }^{\circ} \mathrm{C}$. Rice cultivars in the provinces of Bejing, Hubei, and Heilongjiang provided a relatively lower percentage of rice cultivars with resistance to $4{ }^{\circ} \mathrm{C}$ and exhibited $4(1.53 \%), 4(1.53 \%)$, and $2(0.76 \%)$, respectively. In particular, the province of Heilongjiang lies in the northeast of China but only provides two (0.76\%) OW rice cultivars. However, the province of Jiangsu lies in the south of China but provides the second-highest percentage of rice cultivars with resistance to $4^{\circ} \mathrm{C}$. In summary, altogether $262 \mathrm{OW}$ rice cultivars exhibited a strong resistance to $4^{\circ} \mathrm{C}$ throughout the growth stage under the natural cold-winter field environment.

\section{Evaluation of $\mathrm{OW}$ rice cultivar with extreme resistance to $0^{\circ} \mathrm{C}$}

Altogether 1034 rice cultivars have been exposed repeatedly to the natural field cold-winter environment after being harvested from November 2020 to February 2021(Figure 6.a). Among them, only 24 (2.32\%) Japonica rice cultivars could withstand cold damage of $0{ }^{\circ} \mathrm{C}$ on January 11,12 , and 17,2021 and display withering stems and leaf (Figure 6.b-e). To our surprised, twenty-four OW Japonica rice cultivars could sprout from rice tillering node in March 2021 due to theirs strong root system activity (Figure 6.c-e, Table 5). However, 1010 (97.68\%) rice cultivars with the withered root system could not withstand cold damage at $0{ }^{\circ} \mathrm{C}$ for three days and not sprout from rice tillering node in March 2021 (Figure 6.b-e). No Indica rice cultivars were also found to withstand the resistance to $0^{\circ} \mathrm{C}$. 
Only 24 OW Japonica rice cultivars are distributed in seven different provinces or cities of China and range from 1 (4.16\%) in Jilin province to 5 (20.83\%) in Zhejiang province (Figure 5, Table 3). Of these, the rice germplasm from Zhejiang province had 5 (20.83\%) OW rice cultivars and exhibited the first highest percentage of $\mathrm{OW}$ rice germplasm with resistance to $0{ }^{\circ} \mathrm{C}$ for three days. Rice germplasm in provinces of Anhui, Jiangsu, and Tianjin provides a relatively higher resistance to $0{ }^{\circ} \mathrm{C}$ and displayed 4 (16.67\%) OW rice cultivars in each province. Compared with the 65 (24.81\%) OW rice cultivars in Liaoning province with resistance to $4{ }^{\circ} \mathrm{C}$ in 2020 , only $3(12.5 \%)$ OW rice cultivars could withstand cold damage at $0{ }^{\circ} \mathrm{C}$ for three days in 2021 . This result indicates that $\mathrm{OW}$ rice cultivars could withstand the cold damage at $0{ }^{\circ} \mathrm{C}$ for three days in January 2021 due to the strong root system activity throughout the growth stage under the natural cold-winter field environment. OW rice cultivars are novel rice germplasm for future cold-resistant rice breeding and might provide a new strategy involved in elucidating the molecular mechanism of cold-resistant rice.

\section{Discussion}

Ratooning rice is well known as a special rice cultivation mode, once planted and harvested twice, is of great significance for increasing grain yield, ensuring national food security and improving rice field utilization efficiency (Hhilleris Lamber 1988; Song et al., 2020). In China, there has a 1600 years of history that Chinese farm have planted ratooning rice for high grain yield based on the rice regeneration characteristics in crop production (Xiong et al., 2000; Lin et al., 2015). Currently, the study on the genetics and breeding of ratoon rice and its cultivation technology has been reported. The genetic of ratooning ability in inter-subspecies crosses of rice was quite independent in inheritance (Yan et al., 1992; Liu et al., 1992). Altogether fourteen QTLs affecting ratooning ability were detected on chromosomes 1, 3, 4, 5, 6, 7, 8, and 11 based on the field phenotypic data on regenerative character before the winter coming (Tan et al., 1997; Zheng et al., 2004; Yang et al., 2012; Li et al., 2016). The yield formation of ratooning rice has been determined by the germination ability of axillary buds of first cropping rice (Pu et al., 2018; Xu et al., 2019). The germination ability of axillary buds in ratooning rice was affected by multi-factors including different rice varieties (Duan et al., 2018; Lin et al., 2019), irrigation pattern (Lin et al., 2015), Nutrient (Chen et al., 2014; Chen et al., 2017), rice stubble height (Yi et al., 2009; Lian et al., 2017), temperature and light conditions (Lin et al., 2015), and hormones (Jia 2015; Huang et al., 2017). The present study has promoted the development of ratoon rice. However, the widely planted ratooning rice is a type of special Indica hybrid rice variety, which sprouted from the rice pile axillary after the rice being harvested in crop field and planted once a year but harvested twice in rice production within single year (Chauhan 1985, Xu et al., 2015). The widely planted ratooning rice couldn't survive through the cold-winter season under being exposed to the natural cold-winter field environment; exhibit withering roots, stems, and leaves before the Winter coming.

The overall aim of this study was to evaluate the OW characteristic of the existing rice cultivars throughout China for future studies on the genetic mechanism of $\mathrm{OW}$ rice or even $\mathrm{OW}$ rice variety breeding. In rice production, cold damage is one of the most important abiotic stress factors that restrict the production and development of rice. Twenty-four countries throughout the globe, including China, Japan, and Korea, have suffered from the loss of cold damage in rice production (Zhang et al., 2017). Consequently, breeding a cold-resistant rice variety will be the future important direction of rice genetics and breeding (Liu et al., 2018). However, identifying precisely the cold-resistant rice germplasm is one of the most important steps for the cold-resistant rice variety breeding (Glaszmann et al., 2010; Zhao et al., 2011).

Nowadays, several genes underlying cold-resistant rice have been cloned and functionally identified based on the phenotypic data of cold resistance at the individual growth stage of rice (Liu et al., 2018). However, whether the presently cloned genes underlying the cold-resistant trait according to the cold-resistant phenotypic data at the individual growth period of rice are involved in regulating the OW performance in OW rice germplasm is still a debatable topic. Particularly, the COLD1 has been cloned and functionally identified using the phenotypic data on cold-resistance at the seedling stage of Japonica rice Nipponbare. However, the COLD1 could not provide a perfect explanation of OW field performance of rice because the Nipponbare variety cannot survive through the natural cold-winter field environment at Chongqing, Southwest China. Our knowledge about the phenotypic relationship between the OW field phenomenon of rice and the cold-resistance of rice at several different stages of germination, seedling, booting, and mature growth is still limited. Currently, we still understand little about the cold-resistance at several different stages of germination, seedling, booting, and mature growth of all rice cultivars throughout China, particularly for the OW trait of the evaluated rice cultivars. In this study, we examined the OW trait of Chinese rice cultivars under the natural cold-winter field environment. Only 24 (2.32\%) Japonica rice cultivars could withstand cold damage at $0^{\circ} \mathrm{C}$ for three days in January 2021 , could sprout from rice tillering node in March 2021, and exhibit a strong root system activity throughout the natural cold-winter season. No OW germplasm with indica type was investigated to sprout from rice tillering node March 2021, and the present study indicated that no gene or QTLs are distributed on 12 chromosomes of indica rice cultivars throughout China. The cold-resistance of rice and OW phenomenon of rice might be determined by the strong root system activity. Consequently, future studies on the cold-resistance of rice should put more emphasis on the genetic root system activity (He et al., 1996; Zhang et al., 2001; Liang et al., 2013). In summary, the present cold-resistant rice cultivars will provide some beneficial rice germplasm for future cold-resistant breeding and propose new strategies in elucidating the molecular mechanism of the cold-resistance in rice.

\section{List Of Abbreviations}

OW Overwintering

QTL Quantitative trait locs

$\mathrm{PH} \quad$ Plant height $(\mathrm{cm})$

$\mathrm{DH} \quad$ Date to heading (days)

CV Coefficient variation

Min T Minimum temperatures 
CQNU Chongqing Normal University

CNRRI China National Rice Research Institute

\section{Declarations}

\section{Ethical Approval and Consent to participate}

All analyses were based on the OW rice cultivars, thus no ethical approval and participant's consent are required in this manuscript.

\section{Consent for publication}

Written informed consent for publication was obtained from all participants.

\section{Availability of supporting data}

All data generated or analyzed during this study are included in this published article

\section{Competing interests}

The authors declare that they have no competing interests.

\section{Funding}

This study was supported by Chongqing Natural Science Foundation of China (cstc2021jcyj -msxmX0007), the Open Project Program of State Key Laboratory of Rice Biology (20190202).

\section{Authors' contributions}

Yongshu Liang designed the whole experiment and carried out the study on the evaluation for OW rice cultivars, screened the overwintering cultivated rice, data analysis, and writing the manuscript. Most of rice seeds were provided by Professor Gong (CNRRI). Seven authors of Yuxin Yan, Baobi Wang, Wenao Gong, Huan Wen, Qian Wu, Wenbin Nan, and Xiaojian Qin helped to sow seed and transplant rice seedling over two years and investigate the field data of HD and $\mathrm{PH}$. Hanma Zhang was in charge of the direction of research.

\section{Acknowledgements}

This study was supported by Chongqing Natural Science Foundation of China (cstc2021jcyj -msxmX0007), the Open Project Program of State Key Laboratory of Rice Biology (20190202). Most of rice seeds were provided by Professor Gong (CNRRI)

\section{References}

1. Andaya V, Mackill D (2003) QTLs conferring cold tolerance at the booting stage of rice using recombinant inbred lines from a japonicaxindica cross. Theor Appl Genet 106(6):1084-1090

2. Andaya VC, Tai TH (20007). Fine mapping of the qCTS4 locus associated with seedling cold tolerance in rice (Oryza sativa L.). Molecular Breeding 20(4), 349-358

3. Biswas PS, Khatun H, Das N, Sarker MM, Anisuzzaman M (2017) Mapping and validation of QTLs for cold tolerance at seedling stage in rice from an indica cultivar Habiganj Boro VI (Hbj.BVI). 3 Biotech 7(6):359

4. Cai N (1987) The feasibility of ratooning rice. Hubei Agricultural Sciences 4:2-5. (In Chinese)

5. Chauhan JS (1985) Rice rationing. IRRI Research Paper Series, 102

6. Cheng SH (2010) Chinese super rice breeding. Science Press, Beijing, China. (In Chinese)

7. Chen HF, Zhang ZX, Lin WX (2014) Effects of nitrogen application for bud development on protein expression of ratooning buds of rice. Chinese Journal of Eco-Agriculture 22(12):1405-1413. (In Chinese)

8. Chen HF, Pang XM, Zhang R, Zhang ZX, Xu QH, Fang CX, Li JY, Lin WX (2017) Effects of different water and fertilizer applications on soil enzyme activities and microbial functional diversity in regenerated rice rhizosphere. Acta Agronomica Sinica 43(10):1507-1517. (In Chinese)

9. Dai LY, Lin XH, Ye CR, Ise K, Saito K, Kato A, Xu FR, Yu TQ, Zhang DP (2004) Identification of quantitative trait loci controlling cold tolerance at the reproductive stage in Yunnan landrace of rice, Kunming xiaobaigu. Breed Sci 54(3):253-258

10. Duan MJ, Wu YZ, Tian YC, Liu YW, Liu ZY, Chen F, Jin T (2018) Comparative study on yield and quality of different varieties of ratooning rice.Crops(2):6167. (In Chinese)

11. Endo T, Chiba B, Wagatsuma K, Saeki K, Ando T, Shomura A, Mizubayashi T, Ueda T, Yamamoto T, Nishio T (2016) Detection of QTLs for cold tolerance of rice cultivar 'Kuchum' and effect of QTL pyramiding. Theor Appl Genet 129(3):631-640

12. Fairhurst TH, Dobermann A (2002) Rice in the global food supply. Better Crops International 16:3-6 
13. Fujino K, Sekiguchi H, Matsuda Y, Sugimoto K, Ono K, Yano M (2008) Molecular identification of a major quantitative trait locus, qLTG3-1, controlling lowtemperature germinability in rice. Proceedings of the National Academy of Sciences 105(34), 12623-12628

14. Glaszmann JC, Kilian B, Upadhyaya HD, Varshne RK (2010) Accessing genetic diversity for crop improvement. Curr Opin Plant Biol 13:1-7

15. Hhilleris Lambers D (1988) Varietal improvement for rice rationing: Traits, procedures, collaboxation rice rationing. Rice Ratooning 8:247-255

16. He GC, Shu LH, Zhou YQ, Liao LJ (1996) The overwintering ability of Dongxiang wild rice (Oryza rufipogon) at Wuhan. Journal Wuhan University 42:252254. (In Chinese).

17. Hu FY, Tao DY, Sacks E, Fu BY, Xu P, Li J, Yang Y, Mcnally K, Khush GS, Paterson AH (2003) Convergent evolution of perenniality in rice and sorghum. Proceedings of the National Academy of Sciences 100(7), 4050-4054

18. Huang XJ, Tu NM, Yi ZX, Zhou WX (2017) Effects of different hormone treatments on yield and related physiological characteristics of ratoon rice. Hybrid Rice 32(4):71-75. 80. (In Chinese)

19. Huang GF, Qin SW, Zhang SL, Cai XL, Wu SK, Dao JR, Zhang J, Hu FY (2018) Performance, economics and potential impact of perennial rice PR23 relative to annual rice cultivars at multiple locations in Yunan Province of China. Sustainability 10(4):1086

20. Jiang LX, Ji ST, Li S, Wang LM, Han JJ, Wang LL, Zhu HX, Ji YH (2010) Relationships between rice empty grain rate and low temperature at booting stage in Heilongjiang Province. Chin J Appl Ecol 21(7):1725-1730. (In Chinese)

21. Jia XR (2015) Effects of spraying gibberellin on regeneration rice sprouts and yield in different periods.Modern Agricultural Science and Technology(14):124-125. (In Chinese)

22. Kim SI, Andaya VC, Tai TH (2011) Cold sensitivity in rice (Oryza sativa L.) is strongly correlated with a naturally occurring $199 \mathrm{~V}$ mutation in the multifunctional glutathione transferase isoenzyme GSTZ2. Biochem J 435(2):373-380

23. Kim SM, Suh JP, Lee CK, Lee JH, Kim YG, Jena KK (2014) QTL mapping and development of candidate gene derived DNA markers associated with seedling cold tolerance in rice (Oryza sativa L.). Mol Genet Genomics 289(3):333-343

24. Kuroki M, Saito K, Matsuba S, Yokogami N, Shimizu H, Ando I, Sato Y (2007) A quantitative trait locus for cold tolerance at the booting stage on rice chromosome 8. Theor Appl Genet 115(5):593-600

25. Kuroki M, Saito K, Matsuba S, Yokogami N, Shimizu H, Ando I, Sato Y (2009) Quantitative trait locus analysis for cold tolerance at the booting stage in a rice cultivar, Hatsushizuku. Japan Agricultural Research Quarterly 43(2):115-121

26. Koseki M, Kitazawa N, Yonebayashi S, Maehara Y, Wang ZX, Minobe Y (2010) Identification and fine mapping of a major quantitative trait locus originating from wild rice, controlling cold tolerance at the seedling stage. Mol Genet Genomics 284(1):45-54

27. Li JL, Pan YH, Guo HF, Zhou L, Yang SM, Zhang YZ, Yang JZ, Zhang HL, Li JJ, Zeng YW, Li ZC (2018) Fine mapping of QTL qCTB10-2 that confers cold tolerance at the booting stage in rice. Theor Appl Genet 131(1):157-166

28. Li LF, Liu X, Xie K, Wang YH, Liu F, Lin QY, Wang WY, Yang CY, Lu BY, Liu SJ, Chen LM, Jiang L, Wan JM (2013) qLTG-9, a stable quantitative trait locus for low temperature germination in rice (Oryza sativa L.). Theor Appl Genet 126(9):2313-2322

29. Li XX, Zheng J, Zhou JJ, Yang YQ, Qin XJ, Zhang HM, Liang YS (2016) QTL analysis of rice regenerative ability using the Rejing35/XieB $F_{2}$ population of indica-japonica cross. Molecular Plant Breeding 14(9):2383-2391. (In Chinese)

30. Lian H, Zhou HT, Chen WJ, Li GH, Li MJ, Zhou GH, Sheng JH, Li HX, Xiao CX, Xu YL (2017) Effects of sowing date and height of piles on yield and yield components of ratoon rice.Hunan Agricultural Sciences(4):28-31. (In Chinese)

31. Liang YS, Zhan XD, Wang HM, Gao ZQ, Lin ZC, Chen DB, Shen XH, Cao LY, Cheng SH (2013) Locating QTLs controlling several adult root traits in elite Chinese hybrid rice. Gene 526(2):331-335

32. Liang YS, Zheng J, Yan C, Li XX, Liu SF, Zhou JJ, Qin XJ, Nan WB, Yang YQ, Zhang HM (2018) Locating QTLs controlling overwintering trait in Chinese perennial Dongxiang wild rice. Mol Genet Genomics 293(1):81-93

33. Liang YS, Nan WB, Qin XJ, Zhang HM (2021) Field performance on grain yield and quality and genetic diversity of overwintering cultivated rice (Oryza sativa L.) in southwest China. Sci Rep 11:1846

34. Lin Q, Jiang ZW, Lin Q, Wang YH, Zhang CC, Zhuo CY, Xie HG, Jiang JH, Xie HA, Zhang JF (2019) Establishment and combination screening of identification indexes for strong regeneration of hybrid rice. Fujian Journal of Agricultural Sciences 34(8):873-882. (In Chinese)

35. Lin WX, Chen HF, Zhang ZX, Xu QH, Tu NM, Fang CX, Ren WJ (2015) Research and prospect on physio-ecological properties of ratoon rice yield formation and its key cultivation technology. Chinese Journal of Eco-Agriculture 23(4):392-401. (In Chinese)

36. Liu YS, Zhou KD, Zeng RY, Luo WZ (1992) Evaluation for rice rationing ability of intersub specific hybrid and its relation to agronomic characters of mother plant. Chinese Journal Rice Science 6(4):151-154. (In Chinese)

37. Liu FX, Sun QC, Tan LB, Fu YC, Li DJ, Wang XK (2003) Identification and mapping of quantitative trait loci controlling cold-tolerance of Chinese common wild rice (O.rufipogon Griff.) at booting to flowering stages. Chin Sci Bull 48(19):2068-2071

38. Liu CT, Wang W, Mao BG, Chu CC (2018) Cold stress tolerance in rice: physiological changes, molecular mechanism, and future prospects. Herediats (Beijing) 40(3):171185. (In Chinese)

39. Los DA, Murata N (2004) Membrane fluidity and its roles in the perception of environmental signals. Biochim Biophys Acta 1666(1-2):142-157

40. Lu GW, Wu FQ, Wu WX, Wang HJ, Zheng XM, Zhang YH, Chen XL, Zhou KN, Jin MN, Cheng ZJ, Li XY, Jiang L, Wang HY, Wan JM (2014) Rice LTG1 is involved in adaptive growth and fitness under low ambient temperature. Plant J 78(3):468-480

41. Ma Y, Dai XY, Xu YY, Luo W, Zheng XM, Zeng DL, Pan YJ, Lin XL, Liu HH, Zhang DJ, Xiao J, Guo XY, Xu SJ, Niu YD, Jin JB, Zhang H, Xu X, Li LG, Ma YY, Zhang YL, Lu J, Shao HB (2009) Roles of plant soluble sugars and their responses to plant cold stress. Afr J Biotechnol 8(10):2004-2010 
42. Mittal D, Madhyastha DA, Grover A (2012) Genome-wide transcriptional profiles during temperature and oxidative stress reveal coordinated expression patterns and overlapping regulons in rice.PLoS One7(7), e40899

43. Mittler R, Blumwald E (2015) The roles of ROS and ABA in systemic acquired acclimation. Plant Cell 27(1):64-70

44. Mori M, Onishi K, Tokizono Y, Shinada H, Yoshimura T, Numao Y, Miura H, Sato T (2011) Detection of a novel quantitative trait locus for cold tolerance at the booting stage derived from a tropical japonica rice variety Silewah. Breed Sci 61(1):61-68

45. Oliver SN, Van, Dongen JT, Alfred SC, Mamun EA, Zhao XC, Saini HS, Fernandes SF, Blanchard CL, Sutton BG, Geigenberger P (2005) Cold-induced repression of the rice anther-specific cell wall invertase gene OSINV4 is correlated with sucrose accumulation and pollen sterility. Plant Cell Environment 28(12):1534-1551

46. Paknejad F, Nasri M, Moghadam HRT, Zahedi H, Alahmadi MJ (2007) Effects of drought stress on chlorophyll fluorescence parameters, chlorophyll content and grain yield of wheat cultivars. Journal of Biological Sciences 7(6):841-847

47. Pamplona R (2011) Advanced lipoxidation end-products. Chemico-Biol Interact 192(1-2):14-20

48. Pan YH, Zhang HL, Zhang DL, Li JJ, Xiong HY, Yu JP, Li JL, Rashid MAR, Li GL, Ma XD, Cao GL, Han LZ, Li ZC (2015) Genetic analysis of cold tolerance at the germination and booting stages in rice by association mapping.PLoS One10(3), e0120590

49. Pu LF, Xiang XX (2018) Effects of different sowing dates on yield and its components of C Liangyou 34156 ratoon rice. Hybrid Rice 33(5):39-41. (In Chinese)

50. Qu YY, Wu P, Zhang HL, Zhang HL, Chen CY, Gao YM, Tian YX, Wen F, Li ZC (2008) Mapping QTLs of root morphological traits at different growth stages in rice. Genetica 133:87-200

51. Qin P, Lu HW, Du HL, Wang H, Chen WL, Chen Z, He Q, Ou SJ, Zhang HY, Li XZ, Li XX, Li Y, Liao Y, Gao Q, Tu B, Yuan H, Ma BT, Wang YP, Qian YW, Fan SJ, Li WT, Wang J, He M, Yin JJ, Li T, Jiang N, Chen XW, Liang CZ, Li SG (2021) Pan-genome analysis of 33genetically diverse rice accessions reveals hidden genomic variations. Cell 184:1-17

52. Saito K, Hayano-Saito Y, Kuroki M, Sato Y (2010) Map-based cloning of the rice cold tolerance gene Ctb1. Plant Sci 179(1-2):97-102

53. Sakata T, Oda S, Tsunaga Y, Shomura H, Kawagishi-Kobayashi M, Aya K, Saeki K, Endo T, Nagano K, Kojima M, Sakakibara H, Watanabe M, Matsuoka M, Higashitani A (2014) Reduction of gibberellin by low temperature disrupts pollen development in rice. Plant Physiol 164(4):2011-2019

54. Shakiba E, Edwards JD, Jodari F, Duke SE, Baldo AM, Korniliev P, McCouch SR, Eizenga GC (2017) Genetic architecture of cold tolerance in rice (Oryza sativa. L) Determined through high resolution genome-wide analysis.PLoS One12(3), e0172133

55. Shinada H, Iwata N, Sato T, Fujino K (2013) Genetical and morphological characterization of cold tolerance at fertilization stage in rice. Breed Sci 63(2):197-204

56. Shirasawa S, Endo T, Nakagomi K, Yamaguchi M, Nishio T (2012) Delimitation of a QTL region controlling cold tolerance at booting stage of a cultivar, 'Lijiangxintuanheigu', in rice, Oryza sativa L. Theor Appl Genet 124(5):937-946

57. Song KF, Zhang GB, Xu H, Ma J (2020) A review of research on influencing factors and sustainability of ratoon rice cultivation in China. Acta Pedol Sin 57(6):1365-1377. (In Chinese)

58. Tan ZB, Shen LS, Yuan ZL, Lu CF, Chen Y, Zhou KD, Zhu LH (1997) Identification of QTLs for ratooning ability and grain yield traits of rice and analysis of their genetic effects. Acta Agronomica Sinica 23(3):289-295. (In Chinese)

59. Wang D, Liu JL, Li CG, Kang HX, Wang Y, Tan XQ, Liu MH, Deng YF, Wang ZL, Liu Y, Zhang DY, Xiao YH, Wang GL (2016) Genome-wide association mapping of cold tolerance genes at the seedling stage in rice. Rice 9:61

60. Xi M, Wu WG, Wang JG, Wang HW, Chen G, Xu YZ (2017) Studies on the formation of yield differences in ratooning rice planting. Acta Agriculturae Boreali-sinica 32(1):104-110. (In Chinese)

61. Xiao N, Huang WN, Li AH, Gao Y, Li YH, Pan CH, Ji HJ, Zhang XX, Dai Y, Dai ZY, Chen JM (2015) Fine mapping of the qLOP2 and qPSR2-1 loci associated with chilling stress tolerance of wild rice seedlings. Theor Appl Genet 128(1):173-185

62. Xiao N, Huang WN, Zhang XX, Gao Y, Li AH, Dai Y, Yu L, Liu GQ, Pan CH, Li YH, Dai ZY, Chen JM (2014) Fine mapping of qRC10-2, a quantitative trait locus for cold tolerance of rice roots at seedling and mature stages.PLoS One9(5), e96046

63. Xiong H, Ran ML, Xu FX (2000) Achievements and developments of rationing rice in south of China. Acta Agro Sinica 26(3):297-304. (In Chinese)

64. Xu FX, Xiong H, Zhao GL, Hong S (2002) A study on the canopy characters of mid-season hybrid rice inrelation to their rationing ability. Acta Agronomica Silica 28(3):426-430. (In Chinese)

65. Xu LM, Zhou L, Zeng YW, Wang FM, Zhang HL, Shen SQ, Li ZC (2008) Identification and mapping of quantitative trait loci for cold tolerance at the booting stage in a japonica rice near-isogenic line. Plant Sci 174(3):340-347

66. Xu FX, Xiong H, Zhang L, Zhu YC, Jiang P, Guo XY, Liu M (2015) Progress in research of yield formation of ratooning rice and its high-yielding key regulation technologies. Scientia Agricultura Sinica 48(9):1702-1717. (In Chinese)

67. Xu H, Xu ZM, Wu YZ, Wang DZ, Shi FC, Ma J, Yang HY, Xie L (2019) Performance and mechanized high-yielding cultivation techniques of water-saving and drought resistant hybrid rice combination Hanyou73 grown as ratoon rice in Jianghan Plain. Hybrid Rice 34(6):39-40., 100. (In Chinese)

68. Yuan LP (1966) Male sterility of rice. Chin Sci Bull 17(4):185-188. (In Chinese)

69. Yan YM, Wang XX, Shao QM, Liu BG, Ren CF (1992) Genetics of ratooning ability in inter-subspecies crosses of rice (Oryza sativa L.). Journal of Southwest Agricultural University 14(6):517-521. (In Chinese)

70. Yang CH, Wang YP, Tu B, Li T, Hu L, Li SG (2012) QTL analysis of rice ratooning ability and related agronomic traits by using RIL populations. Acta Agronomica Sinca 38(7):1240-1246. (In Chinese) 
71. Yi ZX, Zhou WX, Tu NM (2009) Effects of stubble height of the main crop on source-sink characteristics and assimilates transportation in ratooning rice. Chinese Journal of Rice Science 23(5):509-516. (In Chinese)

72. Zeng QC, Zhou KD, Zhu Z, Luo Q (2000) Current status in the use of hybrid rice heterosis in China. Chinese Journal Rice Science 14:243-246. (In Chinese)

73. Zhang J, Zheng HG, Aarti A, Pantuwan G, Nguygen TT, Tripathy JN, Sarial AK, Robin S, Babu RC, Nguyen BD, Sarkarung S, Blum A, Nguyen Henry T (2001) Locating genomic regions associated with components of drought resistance in rice: comparative mapping within and across species. Theoretical and Applied Genetic 103:19-29

74. Zhang Q, Chen QH, Wang SL, Hong YH, Wang ZL (2014) Rice and cold stress: methods for its evaluation and summary of cold tolerance-related quantitative trait loci. Rice $7(1): 24$

75. Zhang S, Wang WS, Zhang J, Huang WQ, Xu P, Tao D, Hu FY (2014) The progression of perennial rice breeding and genetic research in China.. In: In: Batello G, Wade LJ, Cox TS, Pogna N, Bozzini A, Chopianty J (eds) Perennial Crops for Food Security. FAO, Rome, pp 27-38

76. Zhang ZY, Li JJ, Pan YH, Li JL, Zhou L, Shi HL, Zeng YW, Guo HF, Yang SM, Zheng WW, Yu JP, Sun XM, Li GL, Ding YL, Ma L, Shen SQ, Dai YL, Zhang HL, Yang SH, Guo Y, Li ZC (2017) Natural variation in CTB4a enhances rice adaptation to cold habitats. Nature Communication 8:14788

77. Zhao JL, Zhang SH, Dong JF, Yang TF, Mao XX, Liu Q, Wang XF, Liu B (2017) A novel functional gene associated with cold tolerance at the seedling stage in rice. Plant Biotechnol J 15(9):1141-1148

78. Zhao JL, Zhang SH, Yang TF, Zeng ZC, Huang ZH, Liu Q, Wang XF, Leach J, Leung H, Liu B (2015) Global transcriptional profiling of a cold-tolerant rice variety under moderate cold stress reveals different cold stress response mechanisms. Physiology Plantarum 154(3):381-394

79. Zhao KK, Tung CW, Eizenga GC, Wright MH, Ali LM, Price AH, Norton GJ, Islam MR, Reynolds A, Mezey J, McClung AM, Bustamante CD, McCouch SR (2011) Genome -wide association mapping reveals a rich genetic architecture of complex traits in Oryza sativa. Nature Communication 2:1-10

80. Zheng JS, Li YZ, Lin WX (2004) Identification of QTL for ratooning ability and grain yield traits in ratoon rice based on SSR marker. Molecular Plant Breeding 2(3):342-347. (In Chinese)

81. Zhou L, Zeng YW, Zheng WW, Tang B, Yang SM, Zhang HL, Li JJ, Li ZC (2010) Fine mapping a QTL qCTB7for cold tolerance at the booting stage on rice chromosome 7 using a near-isogenic line. Theor Appl Genet 121(5):895-905

82. Zhu YJ, Chen K, Mi XF, Chen TX, Ali J, Ye GY, Xu JL, Li ZK (2015) Identification and fine mapping of a stably expressed QTL for cold tolerance at the booting stage using an interconnected breeding population in rice.PLoS One10(12), e0145704

\section{Tables}

Table 1 is available in the Supplementary Files section.

Table 2 OW rice germplasm with resistance to $4^{\circ} \mathrm{C}$ in December 2019 


\begin{tabular}{|c|c|c|c|c|c|c|c|c|}
\hline No. & Cultivars & Provinces & No. & Cultivars & Provinces & No. & Cultivars & Provinces \\
\hline 1 & Nuo10\# & Anhui & 50 & Jijing6\# & Jilin & 99 & Yanjing6" & Jiangsu \\
\hline 2 & Zhongjing86120\# & Anhui & 51 & Jijing $7^{\#}$ & Jilin & 100 & Yanjing7\# & Jiangsu \\
\hline 3 & Wanjing22 \# & Anhui & 52 & Jijing8\# & Jilin & 101 & Yannuo12\# & Jiangsu \\
\hline 4 & R96-2 & Anhui & 53 & Jijing9\# & Jilin & 102 & Yanjing9\# & Jiangsu \\
\hline 5 & Guangjing102 & Anhui & 54 & Jijing10 & Jilin & 103 & Yangjing687 & Jiangsu \\
\hline 6 & Huangnuo2\# & Anhui & 55 & Jijing11\# & Jilin & 104 & Lianjing4 $4^{\#}$ & Jiangsu \\
\hline 7 & Danyujing2 ${ }^{\#}$ & Anhui & 56 & Jijing12\# & Jilin & 105 & Zhen7\# & Jiangsu \\
\hline 8 & Wangjing1 ${ }^{\#}$ & Anhui & 57 & Jijing13\# & Jilin & 106 & Zhen8\# & Jiangsu \\
\hline 9 & Wangjing2 & Anhui & 58 & Jijing14\# & Jilin & 107 & Dandao1 ${ }^{\#}$ & Liaoning \\
\hline 10 & Wangjing $3^{\#}$ & Anhui & 59 & Jijing15\# & Jilin & 108 & Dandao9\# & Liaoning \\
\hline 11 & Wangjing4 $4^{\#}$ & Anhui & 60 & Jijing16\# & Jilin & 109 & Dandao2 $\#$ & Liaoning \\
\hline 12 & Wangjing5 $5^{\#}$ & Anhui & 61 & Jijing17\# & Jilin & 110 & HanG107 & Liaoning \\
\hline 13 & Wangjing6" & Anhui & 62 & Jijing18\# & Jilin & 111 & Dan10\# & Liaoning \\
\hline 14 & Wangjing7" & Anhui & 63 & Jijing19\# & Jilin & 112 & Dan137\# & Liaoning \\
\hline 15 & Xinlong3 ${ }^{\#}$ & Anhui & 64 & Jijing20\# & Jilin & 113 & Gangyu10\# & Liaoning \\
\hline 16 & Zhongjin1 ${ }^{\#}$ & Beijing & 65 & Changbai10\# & Jilin & 114 & Gangyuan3\# & Liaoning \\
\hline 17 & Zhongzuo9843 & Beijing & 66 & Changnong $3^{\#}$ & Jiangsu & 115 & Fuhe80 & Liaoning \\
\hline 18 & Zhongzuo58 & Beijing & 67 & Changnong4 ${ }^{\#}$ & Jiangsu & 116 & Zhuangjing2 $^{\#}$ & Liaoning \\
\hline 19 & Zhongdan4 $^{\#}$ & Beijing & 68 & Wujing $3^{\#}$ & Jiangsu & 117 & Kaijing2 ${ }^{\#}$ & Liaoning \\
\hline 20 & huapei18\# & Henan & 69 & Wunuo8333 & Jiangsu & 118 & Kai9502 & Liaoning \\
\hline 21 & Xinfeng2 $2^{\#}$ & Henan & 70 & Wujing13 & Jiangsu & 119 & Fuhe5 $\#$ & Liaoning \\
\hline 22 & Shuijin3 ${ }^{\#}$ & Henan & 71 & Wujing14 & Jiangsu & 120 & Liaojing371 & Liaoning \\
\hline 23 & Zhenghan6" & Henan & 72 & Wujing15\# & Jiangsu & 121 & Liaojing534 & Liaoning \\
\hline 24 & Xin11 \# & Henan & 73 & Wujing16 & Jiangsu & 122 & Liaojing9 ${ }^{\#}$ & Liaoning \\
\hline 25 & Xin10 & Henan & 74 & Wujing18\# & Jiangsu & 123 & LDC95423 & Liaoning \\
\hline 26 & Xin18\# & Henan & 75 & $9522^{\#}$ & Jiangsu & 124 & Liaojing9\# & Liaoning \\
\hline 27 & Zheng18\# & Henan & 76 & Wujing11 & Jiangsu & 125 & Liaoxing14 & Liaoning \\
\hline 28 & Fangxin $1^{\#}$ & Henan & 77 & Wujing21 & Jiangsu & 126 & Liaoxing15 & Liaoning \\
\hline 29 & Hongguan1 ${ }^{\#}$ & Henan & 78 & Yangjing9538 & Jiangsu & 127 & Liaoxing16\# & Liaoning \\
\hline 30 & Zheng19\# & Henan & 79 & Yangjing7 ${ }^{\#}$ & Jiangsu & 128 & Liaoxing17\# & Liaoning \\
\hline 31 & Wuyoudao1 ${ }^{\#}$ & Heilongjiang & 80 & Yangjing1 ${ }^{\#}$ & Jiangsu & 129 & Tianfeng202 & Liaoning \\
\hline 32 & Longjing1 ${ }^{\#}$ & Heilongjiang & 81 & Yangjing8 ${ }^{\#}$ & Jiangsu & 130 & Shenjing4311 & Liaoning \\
\hline 33 & $\mathrm{E} 1^{\#}$ & Hubei & 82 & W262 & Jiangsu & 131 & Shennong315 & Liaoning \\
\hline 34 & $\mathrm{E} 2^{\#}$ & Hubei & 83 & Nanjing $41^{\#}$ & Jiangsu & 132 & Shendao6" & Liaoning \\
\hline 35 & $\mathrm{E}^{\#}$ & Hubei & 84 & Nanjing43\# & Jiangsu & 133 & Qianchonglang2\# & Liaoning \\
\hline 36 & $\mathrm{E} 4^{\#}$ & Hubei & 85 & Zhendao99 & Jiangsu & 134 & Yanfeng47 & Liaoning \\
\hline 37 & Baijing1 ${ }^{\#}$ & Jilin & 86 & zhengdao10\# & Jiangsu & 135 & Huajing $8^{\#}$ & Liaoning \\
\hline
\end{tabular}




\begin{tabular}{|c|c|c|c|c|c|c|c|c|}
\hline 38 & Changxuan $10^{\#}$ & Jilin & 87 & Huajing $4^{\#}$ & Jiangsu & 136 & Zhuangyu3 ${ }^{\#}$ & Liaoning \\
\hline 39 & Dongdao03056 & Jilin & 88 & Huajing5 ${ }^{\#}$ & Jiangsu & 137 & Xiangfeng00-93 & Liaoning \\
\hline 40 & Jiudao54 ${ }^{\#}$ & Jilin & 89 & Sidao11 & Jiangsu & 138 & Liaoxuan180 & Liaoning \\
\hline 41 & Jiudao55" & Jilin & 90 & Sujing2 ${ }^{\#}$ & Jiangsu & 139 & Shennong90-17 & Liaoning \\
\hline 42 & Jiudao33" & Jilin & 91 & Sujing $8^{\#}$ & Jiangsu & 140 & Liaojing454 & Liaoning \\
\hline 43 & Jiudao46\# & Jilin & 92 & Tongjing1 ${ }^{\#}$ & Jiangsu & 141 & Shennong1\# & Liaoning \\
\hline 44 & Ji96D10 & Jilin & 93 & Xudao4\# & Jiangsu & 142 & Shennong8801 & Liaoning \\
\hline 45 & Jijing1 ${ }^{\#}$ & Jilin & 94 & Xudao6\# & Jiangsu & 143 & Dongxuan2 & Liaoning \\
\hline 46 & Jijing2 ${ }^{\#}$ & Jilin & 95 & Xu91075 & Jiangsu & 144 & Liaonuo10 & Liaoning \\
\hline 47 & Jijing $3^{\#}$ & Jilin & 96 & Xuhan1" & Jiangsu & 145 & Liaojing207 & Liaoning \\
\hline 48 & Jijing $4^{\#}$ & Jilin & 97 & Yan8\# & Jiangsu & 146 & Danjing8 & Liaoning \\
\hline 49 & Jijing5\# & Jilin & 98 & Yan9\# & Jiangsu & 147 & Shennong8718 & Liaoning \\
\hline
\end{tabular}

Table 3 OW rice germplasm with resistance to $4^{\circ} \mathrm{C}$ in December 2019 (Continuous) 


\begin{tabular}{|c|c|c|c|c|c|c|c|c|}
\hline No. & Cultivars & Provinces & No. & Cultivars & Provinces & No. & Cultivars & Provinces \\
\hline 148 & Zhongliao9052 & Liaoning & 187 & $\operatorname{Lin} 10^{\#}$ & Shandong & 226 & Chujing1 ${ }^{\#}$ & Yunnan \\
\hline 149 & Liaojing30 & Liaoning & 188 & Lin9\# & Shandong & 227 & Chujing2 ${ }^{\#}$ & Yunnan \\
\hline 150 & Liaojing931 & Liaoning & 189 & $\operatorname{Lin} 12^{\#}$ & Shandong & 228 & Chujing3 ${ }^{\#}$ & Yunnan \\
\hline 151 & Liaonong979 & Liaoning & 190 & Sheng13 & Shandong & 229 & Chujing $4^{\#}$ & Yunnan \\
\hline 152 & Shennong702 & Liaoning & 191 & Sheng14 & Shandong & 230 & Chujing5 $5^{\#}$ & Yunnan \\
\hline 153 & Shendao4 ${ }^{\#}$ & Liaoning & 192 & Yangguang200 & Shandong & 231 & Fengdao $1^{\#}$ & Yunnan \\
\hline 154 & Shendao5\# & Liaoning & 193 & $\operatorname{Lin} 10^{\#}$ & Shandong & 232 & Fengdao2 ${ }^{\#}$ & Yunnan \\
\hline 155 & Liaojing28 & Liaoning & 194 & Jindao6\# & Shandong & 233 & Fengdao3\# & Yunnan \\
\hline 156 & Shendao2 ${ }^{\#}$ & Liaoning & 195 & Jindnuo $7^{\#}$ & Shandong & 234 & Fengdao $4^{\#}$ & Yunnan \\
\hline 157 & Shendao3 ${ }^{\#}$ & Liaoning & 196 & Jindao8\# & Shandong & 235 & Fengdao $5^{\#}$ & Yunnan \\
\hline 158 & Fuhe6" & Liaoning & 197 & Jindao $10^{\#}$ & Shandong & 236 & Fengdao6" & Yunnan \\
\hline 159 & Liaoxing1 & Liaoning & 198 & $\operatorname{Jin} 291$ & Tianjin & 237 & Fengdao $7^{\#}$ & Yunnan \\
\hline 160 & Fuhe66 & Liaoning & 199 & Jinchuan $1^{\#}$ & Tianjin & 238 & Lijing314 & Yunnan \\
\hline 161 & Shendao $1^{\#}$ & Liaoning & 200 & $\operatorname{Jin} 1187$ & Tianjin & 239 & Dian1 ${ }^{\#}$ & Yunnan \\
\hline 162 & Shendao10\# & Liaoning & 201 & $\operatorname{Jin} 490$ & Tianjin & 240 & Dian2\# & Yunnan \\
\hline 163 & Liaoxing13 & Liaoning & 202 & $\operatorname{Jin} 779$ & Tianjin & 241 & Yunjing1 ${ }^{\#}$ & Yunnan \\
\hline 164 & Liaoxing18 & Liaoning & 203 & $\operatorname{Jin} 1229$ & Tianjin & 242 & Yunjing2 ${ }^{\#}$ & Yunnan \\
\hline 165 & Liaoxing19 & Liaoning & 204 & Jin937 & Tianjin & 243 & Yunjing3 ${ }^{\#}$ & Yunnan \\
\hline 166 & Liaoxing20 & Liaoning & 205 & Jin9901 & Tianjin & 244 & Yunjing4 $4^{\#}$ & Yunnan \\
\hline 167 & Han58 & Liaoning & 206 & Jinxing1 ${ }^{\#}$ & Tianjin & 245 & Yunjing5 ${ }^{\#}$ & Yunnan \\
\hline 168 & Shennong514 & Liaoning & 207 & Huayu409 & Tianjin & 246 & Yunjing6 ${ }^{\#}$ & Yunnan \\
\hline 169 & Ying8433 & Liaoning & 208 & Jin9618 & Tianjin & 247 & Yunjing7 $7^{\#}$ & Yunnan \\
\hline 170 & Liao135 & Liaoning & 209 & Huayu446 & Tianjin & 248 & Wennuo $1^{\#}$ & Yunnan \\
\hline 171 & Liaonuo & Liaoning & 210 & Jinyou9702 & Tianjin & 249 & Yunjingyou5 & Yunnan \\
\hline 172 & Ning29\# & Ningxia & 211 & Jinnuo6\# & Tianjin & 250 & Jiashao2 ${ }^{\#}$ & Zhejiang \\
\hline 173 & Ning2 ${ }^{\#}$ & Ningxia & 212 & Jinxianghei38 & Tianjin & 251 & Jia65 & Zhejiang \\
\hline 174 & Ning $3^{\#}$ & Ningxia & 213 & Jinyuan101 & Tianjin & 252 & Zhenuo36 & Zhejiang \\
\hline 175 & Ning36" & Ningxia & 214 & Jinyuan38 & Tianjin & 253 & Zhejing22 & Zhejiang \\
\hline 176 & Tong35" & Ningxia & 215 & Jinyuan45 & Tianjin & 254 & Xiushui390 & Zhejiang \\
\hline 177 & Ning23\# & Ningxia & 216 & Jinyuan13 \# & Tianjin & 255 & Xiushui42 & Zhejiang \\
\hline 178 & Ning38\# & Ningxia & 217 & Jinyuan5 ${ }^{\#}$ & Tianjin & 256 & Xiushui52 & Zhejiang \\
\hline 179 & Ning40\# & Ningxia & 218 & Jinyuan85 & Tianjin & 257 & Bing95-13 & Zhejiang \\
\hline 180 & Ning41 & Ningxia & 219 & Jinyuan9540 & Tianjin & 258 & Xianghu914 & Zhejiang \\
\hline 181 & Ning31 \# & Ningxia & 220 & Jinyuan17 & Tianjin & 259 & Zhejing30 & Zhejiang \\
\hline 182 & Ning39\# & Ningxia & 221 & Jinyuan24 & Tianjin & 260 & Yuanjing41 & Zhejiang \\
\hline 183 & Ningyou2 ${ }^{\#}$ & Ningxia & 222 & JinyuanD1 & Tianjin & 261 & Zhejing23 & Zhejiang \\
\hline 184 & Ning20\# & Ningxia & 223 & Jinzasi & Tianjin & 262 & Jiahe218 & Zhejiang \\
\hline
\end{tabular}




\begin{tabular}{llllll}
185 & Ning25 & Ningxia & 224 & Jindao5 $^{\#}$ & Tianjin \\
\hline 186 & Ning32 $^{\#}$ & Ningxia & 225 & Jin9540 & Tianjin
\end{tabular}

Table 4 Geographic distribution of OW rice germplasm with resistance to $4^{\circ} \mathrm{C}$ in December 2019

\begin{tabular}{|c|c|c|c|c|c|c|c|c|c|c|c|c|c|c|}
\hline Provinces & & Anhui & Beijing & Henan & Heilongjiang & Hubei & Jilin & Jiangsu & Liaoning & Ningxia & Shanxi & Tianjin & Yunnan & Zhejiaı \\
\hline \multirow[t]{2}{*}{ Numbers } & No. & 15 & 4 & 11 & 2 & 4 & 29 & 41 & 65 & 15 & 11 & 28 & 24 & 13 \\
\hline & $\%$ & 5.73 & 1.53 & 4.20 & 0.76 & 1.53 & 11.07 & 15.65 & 24.81 & 5.73 & 4.19 & 10.68 & 9.16 & 4.96 \\
\hline
\end{tabular}

Table 5 Geographic distribution of OW rice cultivar with resistance to $0^{\circ} \mathrm{C}$

\begin{tabular}{|c|c|c|c|}
\hline \multirow[t]{2}{*}{ Provinces } & \multirow[t]{2}{*}{ Cultivars } & \multicolumn{2}{|c|}{ Numbers } \\
\hline & & No. & $(\%)$ \\
\hline \multirow[t]{4}{*}{ Anhui } & Wandao90\# & \multirow[t]{4}{*}{4} & \multirow[t]{4}{*}{16.67} \\
\hline & Huangnuo2 ${ }^{\#}$ & & \\
\hline & Wandao82\# & & \\
\hline & WangengM1148 & & \\
\hline \multirow[t]{3}{*}{ Hubei } & Ewan15\# & \multirow[t]{3}{*}{3} & \multirow[t]{3}{*}{12.50} \\
\hline & Ewan17"\# & & \\
\hline & Ewan13\# & & \\
\hline \multirow[t]{4}{*}{ Jiangsu } & Changnonggeng $3^{\#}$ & \multirow[t]{4}{*}{4} & \multirow[t]{4}{*}{16.67} \\
\hline & Suxianggeng2 $2^{\#}$ & & \\
\hline & Sugeng $8^{\#}$ & & \\
\hline & Zhendao7 $^{\#}$ & & \\
\hline Jilin & Changbai7 & 1 & 4.16 \\
\hline \multirow[t]{3}{*}{ Liaoning } & 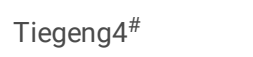 & \multirow[t]{3}{*}{3} & \multirow[t]{3}{*}{12.50} \\
\hline & liaoyan241 & & \\
\hline & Shendao3 ${ }^{\#}$ & & \\
\hline \multirow[t]{4}{*}{ Tianjin } & Jindao1187" & \multirow{4}{*}{4} & \multirow[t]{4}{*}{16.67} \\
\hline & Jinyou2006" & & \\
\hline & Jinyuan5 ${ }^{\#}$ & & \\
\hline & Jingengza4 $4^{\#}$ & & \\
\hline \multirow[t]{5}{*}{ Zhejiang } & Zhenuo36\# & \multirow[t]{5}{*}{5} & \multirow[t]{5}{*}{20.83} \\
\hline & Xiushui42\# & & \\
\hline & Xiushui52"\# & & \\
\hline & Zhegeng23\# & & \\
\hline & Jiashao2 ${ }^{\#}$ & & \\
\hline Total & & 24 & 100 \\
\hline
\end{tabular}

\section{Figures}




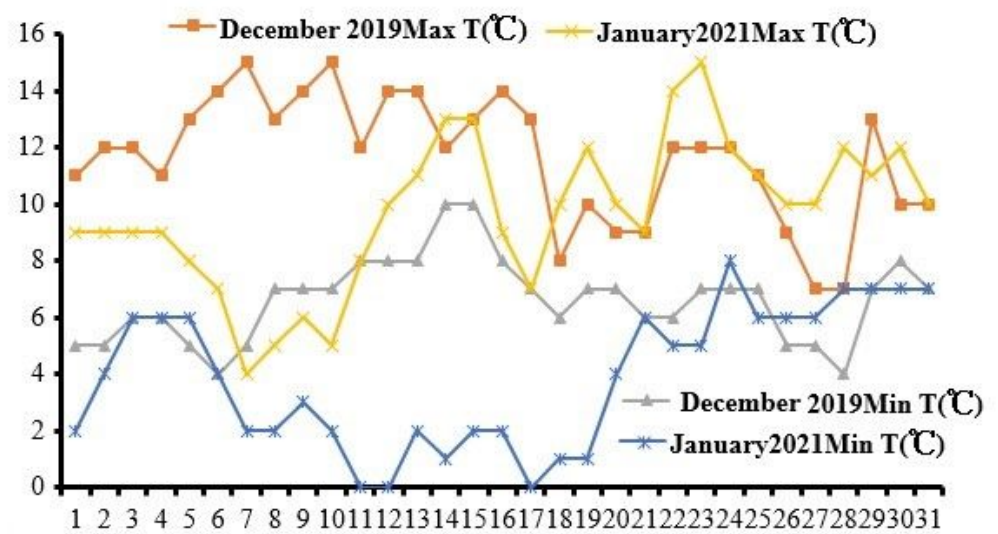

Figure 1 Daily maximum $\left(\operatorname{MaxT},{ }^{\circ} \mathrm{C}\right)$ and minimum temperauter $\left(\operatorname{Min} T,{ }^{\circ} \mathrm{C}\right)$ in December 2019 and January 2021

Figure 1

See image above for figure legend.

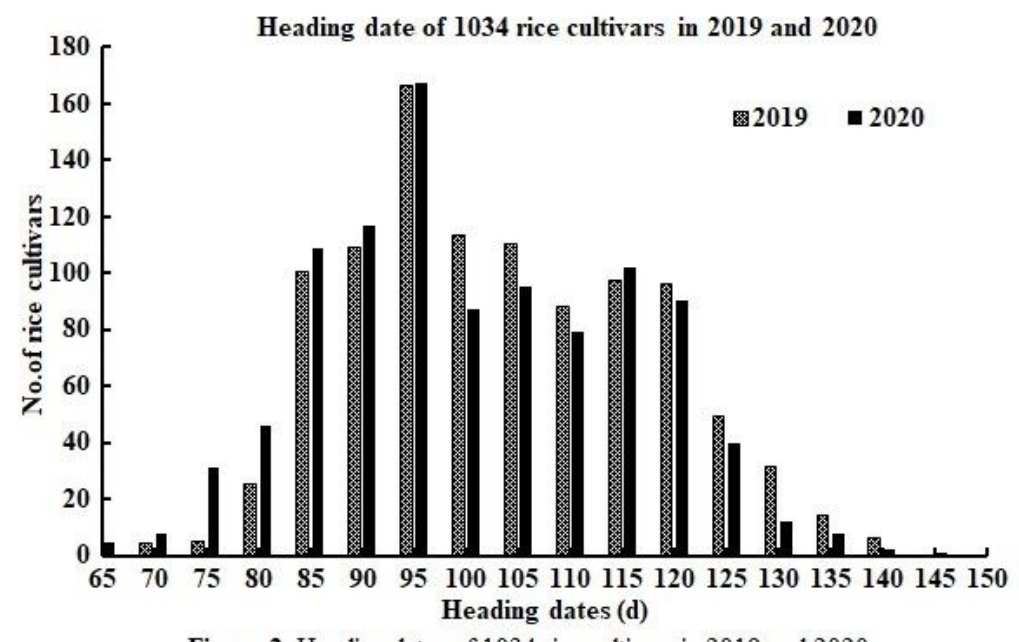

Figure 2 Heading dates of 1034 rice cultivars in 2019 and 2020

Figure 2

See image above for figure legend.

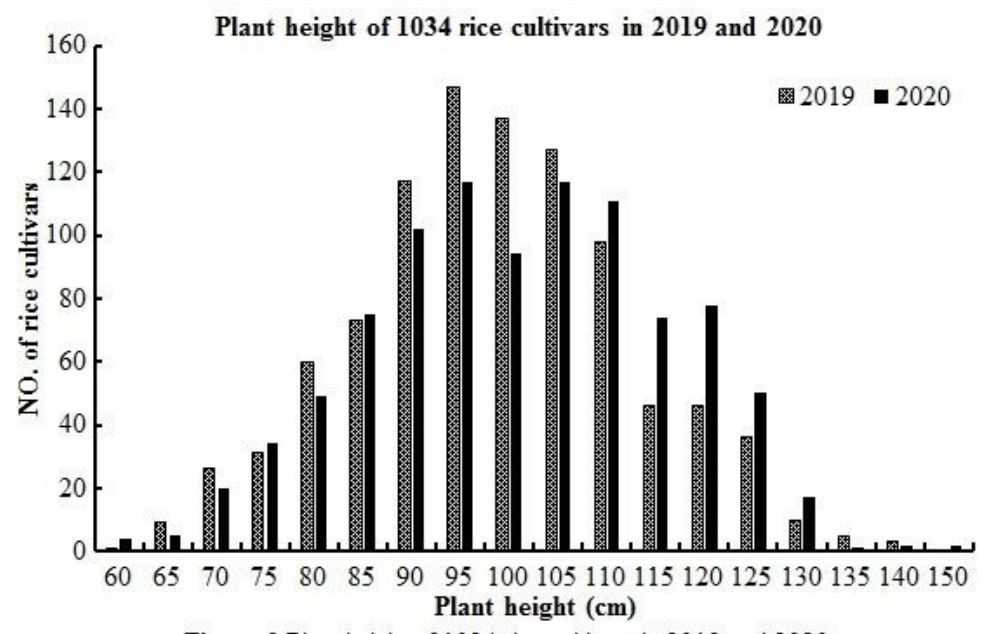

Figure 3 Plant height of 1034 rice cultivars in 2019 and 2020

Figure 3

See image above for figure legend. 


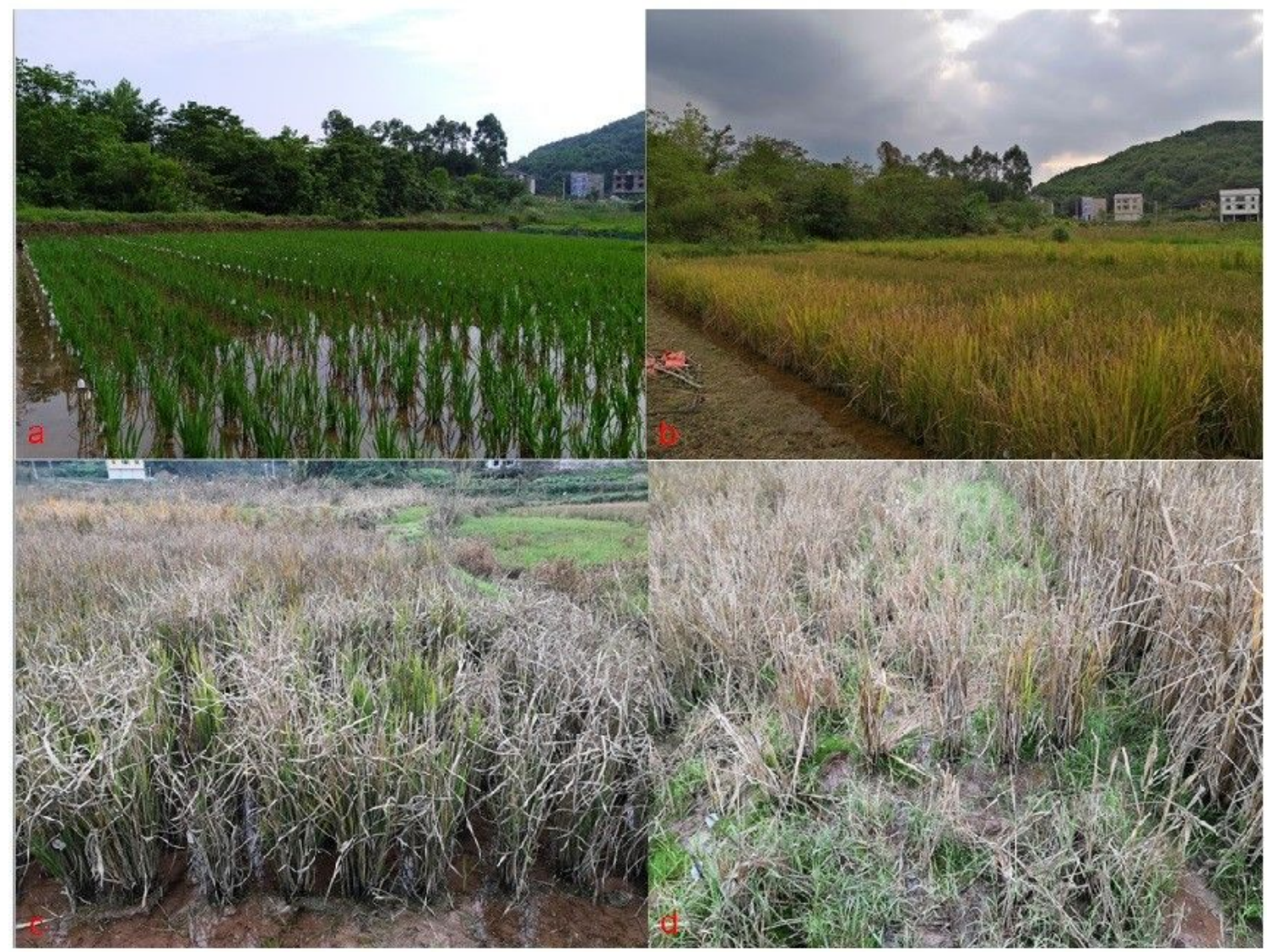

Figure 4 OW rice germplasm evaluated from spring 2019 to spring 2020

a. Field performance of 1034 rice cultivars transplanted in May 2019; b. Field performances of 1034 rice cultivars in December 2019; c-d. OW rice cultivars germinated in March and April 2020

\section{Figure 4}

See image above for figure legend.

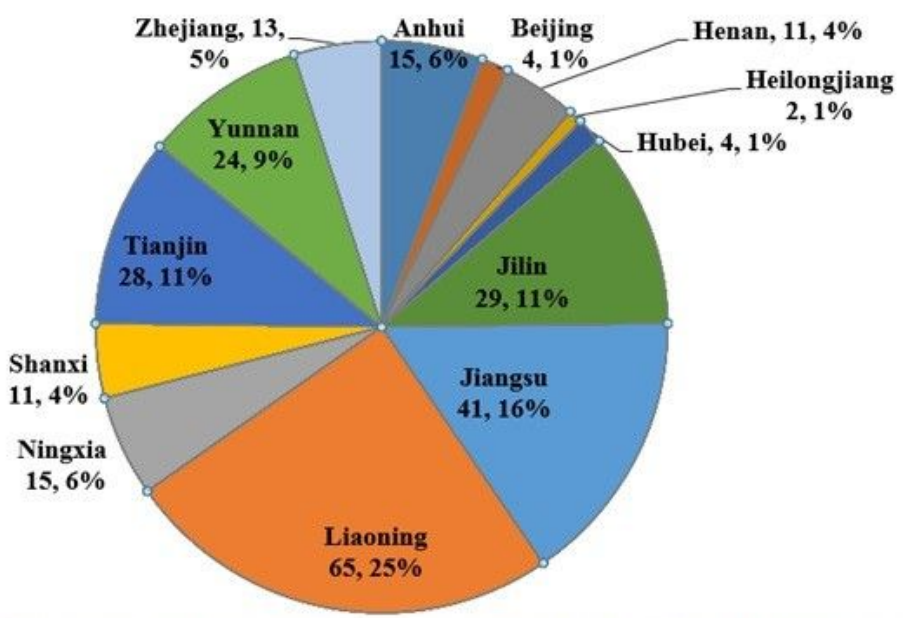

Figure 5 Geographic distribution of OW rice cultivars with cold-resistance to $4^{\circ} \mathrm{C}$ in December 2019

\section{Figure 5}

See image above for figure legend. 


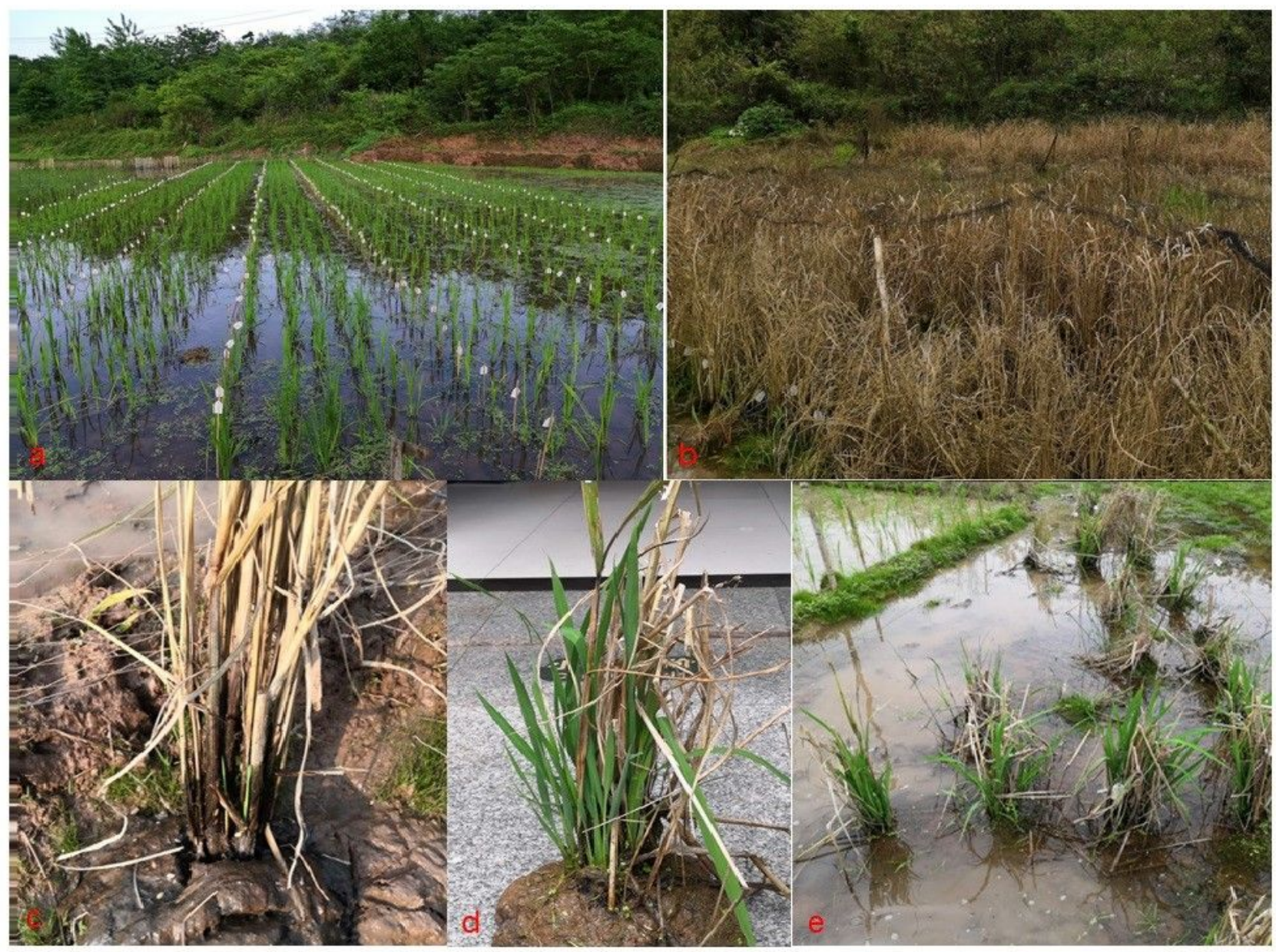

Figure 6 OW rice germplasm evaluated from spring 2020 to spring 2021

a. Field performance of 1034 rice cultivars transplanted in April 2020; b. Field performance of 1034 rice cultivars in February 2021; c-e. OW rice germplasm sprouted from tillering node in March and April 2021.

\section{Figure 6}

See image above for figure legend.

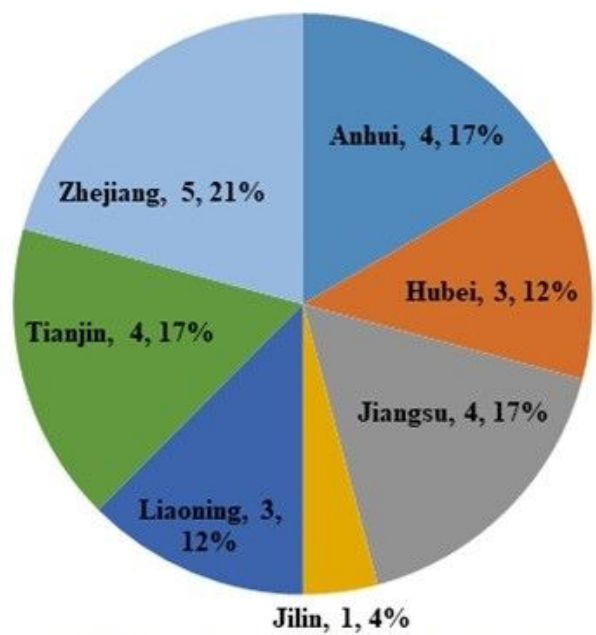

Figure 7 Geographic distribution of $\mathrm{OW}$ rice cultivar with cold-resistance to $0{ }^{\circ} \mathrm{C}$ in January 2021

Figure 7

See image above for figure legend.

\section{Supplementary Files}


This is a list of supplementary files associated with this preprint. Click to download.

- Table1.docx

Page $17 / 17$ 